\title{
GRZEGORZ WIELKI WOBEC PROBLEMÓW W RELACJACH MIĘDZY CHRZEŚCIJANAMI I ŻYDAMI NA PODSTAWIE SWEGO REGISTRUM EPISTULARUM
}

Spuścizna epistolograficzna papieża Grzegorza Wielkiego należy do najcenniejszych źródeł wiedzy o funkcjonowaniu społeczności żydowskiej w obrębie zachodniej części chrześcijańskiego świata na przełomie VI i VII wieku. Dzięki licznym interwencjom papieża w sprawach pojawiających się na styku życia wspólnoty chrześcijańskiej i żydowskiej zachowały się w jego listach cenne informacje pozwalające poznać funkcjonowanie obu społeczności. Listy dotyczą najczęściej spraw związanych z wiarą, z pozyskiwaniem wyznawców spośród żydów ${ }^{*}$, ale także konfliktów pojawiających się pomiędzy wyznawcami judaizmu i chrześcijanami. Święty Grzegorz wkraczał zdecydowanie tam, gdzie gwałcone były zasady chroniące życie tejże wspólnoty, jak na przykład prawo zakazujące żydom posiadania służby i niewolników chrześcijańskich. Zdarzało się jednak również, że źle pojmowana i realizowana gorliwość religijna niektórych chrześcijan, czasem również duchownych, skłaniała papieża do interwencji mających na celu obronę żydów i rozwiązywanie trudności przez wspólnotę chrześcijańską w duchu ewangelicznym. Różnego rodzaju szczegółowe rozwiązania starał się podejmować św. Grzegorz w oparciu o stanowione przez cesarzy prawa. Tam, gdzie to nie wystarczało, odwoływał się do Ewangelii.

Warto przyjrzeć się nieco ówczesnej sytuacji prawnej społeczności żydowskiej, aby na tym tle uzmysłowić sobie, jaki był duch rozstrzygnięć papieża Grzegorza w dotyczących ich sprawach ${ }^{1}$.

* Zgodnie z zasadami języka polskiego wyraz „żyd” odnoszący się nie do narodowości, lecz oznaczający przynależność religijną, piszemy małą literą. W Listach świętego Grzegorza mamy do czynienia przede wszystkim z konfesyjnym pojęciem słów takich jak żyd, żydzi. Tam, gdzie może chodzić o przynależność etniczną słowa te pisane będą oczywiście wielką literą.

${ }^{1} \mathrm{Na}$ temat stosunku św. Grzegorza do żydów pisała L. Cracco Ruggini, Pagani, Ebrei e cristiani: odio sociologico e odio teologico (XXVI Settimana di Studi), Spoleto 1980, 13-117; taż, Grégoire le Grand et le monde Byzantin, w: Grégoire le Grand (Colloques de Chantilly 1982), Paris 1986, 83-94; taż, Pietro di Grado: giudaismo e conversioni nel mondo antico, w: Grado nella storia e nell'arte, I, Udine 1980, 139-160; S. Boesch Gaiano, Per una storia degli Ebrei in Occidente tra Antichità e Medioevo. La testimonianza di Gregorio Magno, ,QQuaderni Medievali” 8 (1979) 12-43. 
Obowiązek troski o chrześcijańskie państwo i jego społeczność spoczywał głównie na cesarzu, który stał zarazem na straży wydawanych przez siebie praw. Podejmowane przez papieża interwencje dokonywane więc były w ramach prawa stanowionego przez cesarza, z którym na przełomie VI i VII wieku nadal utożsamiano władzę świecką, mimo zmniejszającego się wpływu cesarstwa na Zachodzie. W tym czasie fundamentem praw wydawanych przez imperatorów od IV wieku, a mających na celu regulowanie życia religijnego, był edykt tessalonicki Teodozjusza Wielkiego z 28 lutego 380 r., nakazujący wszystkim poddanym przyjęcie wiary wyznawanej przez biskupów Rzymu oraz Aleksandrii. Czynił on chrześcijaństwo religią państwową i zakazywał jednocześnie praktykowania kultu pogańskiego. Ustawy następujące po nim zakazywały równiez kultu heretykom - najpierw publicznego, potem także prywatnego. Jednak w obrębie nowo powstałego chrześcijańskiego państwa odmienny status prawny przysługiwał społeczności żydowskiej. Wprawdzie prawo zaostrzało przepisy dotyczące żydów, podobnie jak to miało miejsce w przypadku heretyków, jednak zakaz sprawowania kultu, w odróżnieniu od pogan i heretyków, żydów nie objął. Było to dla nich bez wątpienia szczególnym przywilejem ${ }^{2}$.

W miarę upływu czasu i pojawiania się różnych problemów cesarze dodawali nowe przepisy, określające możliwości działania żydów w różnych dziedzinach życia. Pierwszym ich zbiorem, który istotnie wyznaczał sposób działania władzy wobec niechrześcijan była XVI księga Kodeksu Teodozjusza, sporządzonego między 429 a 439 rokiem, po nim zaś ustawodawstwo Justyniana sformułowane w Codex Iustinianeus (529 i 534 - druga edycja) oraz zbiór praw zawartych w tzw. Corpus iuris civilis - Digesta, Pandecta, Institutiones (533) i Novellae (po 534).

Grzegorz Wielki, mimo wyraźnie osłabionych więzi ze Wschodem, był i czuł się formalnie poddanym cesarza. Stąd też działając w sprawach świeckich starał się stosować do przepisów wydawanych przez cesarzy ${ }^{3}$. Gdy Italia została zagrożona najazdem Longobardów, namiestnik imperatora ograniczył się do obrony egzarchatu raweńskiego i nie wykazywał dostatecznego zainteresowania sprawami pozostałej części Italii. Kiedy zaś władza cesarska nie chciała, nie potrafiła czy nie mogła działać, papież i biskupi zaczęli przejmować liczne jej zadania na terenach, na których sprawowali swe funkcje kościelne. Stąd też

2 Por. E. Bammel, Gregor der Grosse und die Juden, w: Gregorio Magno e il suo tempo (XIX incontro di studiosi dell'antichità cristiana in collaborazione con l'École française de Rome, Roma, 9-12 maggio 1990), SEA 33, Roma 1991, 283.

${ }^{3}$ Por. sformułowania w listach odnoszące się do jego stosunku do cesarza np. Epistolae III 61, CCL 140, 209: „Ego [...] indignus pietatis vestrae famulus”; tamże V 37, CCL 140, 308: „Piissimus atque a Deo constitutus Dominus noster [...]”; tamże I 5, CCL 140, 7: „Ecce serenissimus Dominus imperator”; tamże I 26, CCL 140, 34: „Sed quia contraire non est Domini disponentis arbitrio, obedienter secutus sum quod misericors de me regentis manus voluit operari". 
rozwiązywanie spraw związanych z żydami poleca papież w swej korespondencji przede wszystkim ich pieczy. Zaleca jednocześnie postawę zgodną z wcześniejszym prawodawstwem, zakazującym wobec pogan i żydów stosowania przymusu dopóki wiodą oni życie spokojne ${ }^{4}$.

\section{WOLNOŚĆ WYZNANIA}

1. Wolność wyznania żydów. Największa grupa podejmowanych w listach spraw związanych z żydami dotyczy wolności religijnej. Listy świadczą o wielkim osobistym zaangażowaniu i wysiłku, jaki wkładał papież w zapewnienie im swobody wyznania. Widać też, że decyzje podejmowane przez św. Grzegorza w sprawach żydów nie ograniczały się do respektowania prawa cesarskiego, lecz w wielu przypadkach wychodzą naprzeciw ich oczekiwaniom; dotyczy to zwłaszcza praktyk religijnych. Listy pokazują też, iz żydzi mieli niezwykłą łatwość dostępu do papieża, któremu nierzadko osobiście przedstawiali swoje sprawy ${ }^{5}$.

Jedna z pierwszych interwencji papieża wiązała się z odebraniem żydom przez Piotra, biskupa miasta Terracina, miejsca na gromadzenie się w celu sprawowania kultu. Usunąwszy ich już raz z jednego miejsca przeniósł na nowe, które ponownie odebrał. Spotkało się to jednak ze sprzeciwem Grzegorza, który polecił biskupowi przywrócić żydom możliwość gromadzenia się według zwyczaju w miejscu, na które wcześniej biskup wyraził zgodę. Papież wolał, aby Piotr stosował się w tym przypadku do zasady, że ludzi nie zgadzających się z chrześcijańską wiarą należy pozyskiwać dla niej łaskawością, dobrocią, upominaniem, namową i słodyczą wymowy słowa Bożego, nie zaś odstraszaniem przez zbytnią surowość, gdyż tego rodzaju postępowanie oparte na groźbach i strachu odpycha od wiary zamiast do niej przekonywać ${ }^{6}$.

Chcąc wyjść naprzeciw oczekiwaniom żydów Grzegorz stara się uwzględniać również dobro społeczności chrześcijańskiej. Kiedy bowiem okazało się, iż wspomniane miejsce kultu znajduje się tak blisko kościoła, iż dochodzą do niego głosy śpiewów, polecił biskupom sąsiednich miast - Bakaudzie z Formiae i Agnellowi z Fundi, aby wraz z Piotrem z Terraciny zbadali sprawę i w razie potrzeby wyznaczyli żydom inne miejsce, a w ten sposób zapewnili również swobodę sprawowania kultu w kościele. Zobowiązuje jednocześnie do znalezienia takiego rozwiązania, aby w przyszłości nie wnoszono już więcej skarg w tej sprawie ${ }^{7}$.

${ }^{4}$ Por. tamże II 45, CCL 140, 137: „Praedictos vero Hebraeos gravari vel affligi contra rationis ordinem prohibemus. Sed sicut Romanis vivere legibus permittuntur, annuente iustitia actosque suos ut norunt, nullo impediente, disponant".

${ }^{5}$ Por. tamze I 10; I 34; I 45; IX 38; IX 40; IX 196.

${ }^{6}$ Por. tamże I 34.

${ }^{7}$ Por. tamze II 45. 
Wypada podkreślić, że prawo rzymskie gwarantowało żydom możliwość odbywania zgromadzeń i zachowanie ustalonych miejsc kultu. Już ustawa Teodozjusza z 393 r. przypominając, że żadne prawo nie jest wymierzone przeciw żydom, wyraża oburzenie na to, że w niektórych miejscach zakazywano im zgromadzeń i nakazuje surowo powstrzymać tych, którzy działając rzekomo w imię religii chrześcijańskiej próbują burzyć i grabić synagogi ${ }^{8}$. Do jednego z podobnych przypadków odnosi się papież w liście do Januariusza, biskupa Caralis: jeden z nowo nawróconych żydów imieniem Piotr w dzień Wielkanocy wbrew woli i mimo wcześniejszego zakazu biskupa zajął synagogę i umieścił w niej ,,wizerunek Bożej Rodzicielki i Pana naszego, czcigodny krzyż oraz biały całun, którym był okryty wychodząc ze źródła”. Grzegorz chwali intencje Januariusza i nakazuje wobec dokonanego aktu usunąć ze czcią wizerunki święte oraz krzyż i zwrócić synagogę żydom. Powołuje się przy tym na prawo, które wprawdzie nie pozwala im budować nowych synagog, spokojnie jednak pozwala posiadać stare ${ }^{9}$.

Święty Grzegorz zawsze bardzo zdecydowanie występuje w obronie żydów, kiedy prawo stoi po ich stronie, nawet w przypadku, gdy wiąże się to z upomnieniem wobec biskupa i zmianą jego decyzji. Interwencja o takim charakterze miała m.in. miejsce w Panormos (Palermo), gdzie doszło do sporu o miejsca kultu między żydami i miejscowym biskupem. Papież uprzedzony przez gminę żydowską w Rzymie wysłał w czerwcu 598 r. biskupowi Wiktorowi list z upomnieniem, aby wstrzymał się z poświęceniem miejsc, które, jak wynika z docierających do papieża wieści, zostały bez powodu zabrane ${ }^{10}$. Grzegorz przypomina zarazem, iż prawo, które dozwala czynić żydom w synagogach to, co się mu nie sprzeciwia, zarazem chroni ich przed krzywdą, gdyby ktoś nie dozwalał im czynić tego, na co mają zezwolenie. W związku z tym papież poleca Wiktorowi zapoznanie się z obowiązującym prawem i takie działanie, aby sam biskup nie czynił nic niesprawiedliwego i nie wyrządzał niesłusznie żydom krzywdy. Gdyby zaś spór tego wymagał, nakazuje, aby strony powołały sędziów, a w razie braku możliwości rozstrzygnięcia sprawy na miejscu poleca przekazać ją do Rzymu $^{11}$. Z listu wysłanego w październiku tego samego roku do obrońcy Fantyna w Panormos dowiadujemy się, iż przedmiotem sporu było bezpodstawne zajęcie i poświęcenie przez biskupa synagog z ich hospicjami. Ponieważ jednak, jak pisze papież, to, ,co raz zostało poświęcone, nie może następ-

${ }^{8}$ Por. CTh XVI 8, 9, SCh 497, 382: De Iudaeis, coelicolis et Samaritanis: „Iudaeorum sectam nulla lege prohibitam, satis constat. Unde graviter commovemur, interdictos quibusdam locis eorum fuisse conventus. Sublimis igitur magnitudo tua, hac iussione suscepta, nimietatem eorum, qui sub Christianae religionis nomine illicita quaeque praesumunt, et destruere synagogas atque exspoliare conantur, congrua severitate cohibebit".

9 Por. Epistolae IX 196.

${ }^{10}$ Por. tamże VIII 25.

11 Por. tamże. 
nie zostać zwrócone żydom", poleca miejscowemu patrycjuszowi oraz opatowi oszacować wartość poświęconych synagog i hospicjów, aby na tej podstawie biskup wypłacił stosowną sumę tytułem odszkodowania. Nakazuje również, jeśli okaże się prawdą, dopilnować, aby żydzi otrzymali z powrotem zabrane im księgi i ozdoby ${ }^{12}$.

Równie stanowczo staje papież w obronie wolności sprawowania kultu przez żydów. Jego list skierowany do biskupa Paschazjusza z Neapolu jest świadectwem nie tylko jednorazowej interwencji św. Grzegorza, lecz daje obraz jego zapatrywań na to, jak winno się w duchu chrześcijańskim kształtować relacje z wyznawcami religii Mojżeszowej. Napomnienie, skierowane do biskupa, dotyczyło bowiem powstrzymania ludzi przeszkadzających żydom w obchodzeniu świąt, a nawet usiłujących doprowadzić do tego, aby w ogóle nie mieli oni możliwości świętowania. Papież nakazuje zapewnienie im swobodnej możliwości obchodzenia i celebrowania świąt oraz dni wolnych, tak jak dotychczas czynili to oni oraz ich rodzice. Napomina równocześnie biskupa, aby nie tylko nie niepokoił ich w sprawie świętowania, ale miał na uwadze, iż zjednywać do prawdziwej religii chrześcijańskiej można jedynie przychylnością i łagodnym postępowaniem. Utrudnianie zaś żydom praktyk i zabranianie im życia według długoletnich zwyczajów nie przyczyni się w niczym ich nawróceniu na wiarę. Według papieża można to osiągnąć jedynie przekonywaniem ich o prawdzie głoszonej przez chrześcijan Ewangelii na podstawie ich własnych ksiąg ${ }^{13}$.

Powyższy list do Paschazjusza, jak również przywoływane wcześniej ${ }^{14}$ świadczą o stałej postawie św. Grzegorza wobec prób nawracania żydów inaczej, jak tylko przy odwołaniu się do ich dobrej woli. Zakazuje więc zmuszania żydów do chrztu również w liście do biskupów Wirgiliusza z Arelate oraz Teodora z Marsylii podkreślając, że właściwym sposobem doprowadzania ich do wiary jest głoszenie słowa Bożego ${ }^{15}$. Zamiast przymusu za bardziej skuteczne uznaje okazanie im solidarności poprzez zmniejszenie opłat czynszowych, gdyby mieli się nawrócićc ${ }^{16}$.

Tego rodzaju stanowisko było zasadniczo przeciwne praktykom stosowanym przez władców barbarzyńskich, którzy wyznając chrześcijaństwo usiłowali przymuszać doń również żydów. Wymownym tego świadectwem jest informacja zapisana przez Grzegorza z Tours w Historii Franków ${ }^{17}$ dotycząca Chilperyka (567-584), króla Neustrii, który nakazał doprowadzanie siłą żydów do chrztu. Podobna praktyka stosowana była w królestwie Austrazji za panowania Childeberta (570-595). Stosowanie przymusu wobec żydów nie ominęło

\footnotetext{
12 Por. tamże IX 38.

13 Por. tamże XIII 13.

14 Por. tamże I 34 oraz II 45 i VIII 25.

15 Por. tamże I 45.

${ }^{16}$ Por. tamże II 50.

17 Por. Gregorius Turonensis, Historia Francorum, VI 17
} 
również Hiszpanii. Z początkiem swego panowania król Sysebut (612-621) wydał tam prawo, wedle którego żyd odmawiający przyjęcia chrztu miał być skazany na karę stu batów oraz wygnanie ${ }^{18}$.

Odbywający się mniej więcej 20 lat później synod w Toledo wypowiedział się jednak w duchu rozstrzygnięć papieża Grzegorza stwierdzając, iż nikogo nie wolno siłą przymuszać do chrztu. Jeśli bowiem ma być wolą Boga, aby człowiek doszedł do poznania prawdy i zbawienia, Bóg nie odmówi mu łaski dojścia do owych dóbr za pomocą wolnej woli ${ }^{19}$. Od strony praktycznej miało to również znaczenie dla społeczności chrześcijańskiej - zabezpieczało jej integralność chroniąc przed wnikaniem tych, którzy wbrew woli zmuszeni do chrztu, nie nawracali się rzeczywiście i wyznawali swoją dawną wiarę potajemnie lub powracali do niej przy najbliższej nadarzającej się okazji dając często okazję do zgorszenia ${ }^{20}$.

Ustawodawstwo kościelne poszczególnych prowincji nie szło w parze z próbami ujednolicenia postępowania wobec żydów w ramach cesarstwa oraz na obszarze jego wpływów. W Galii zmuszanie żydów do chrztu było powszechną praktyką. Przeciw niej występuje św. Grzegorz już w pierwszym roku swojego pontyfikatu w liście skierowanym do biskupów Arles i Marsylii ${ }^{21}$. Władza cesarska i królewska nie były jednak skłonne przyjmować rozwiązań podobnych do tych, jakie zalecał św. Grzegorz. Żyjący w VII wieku kronikarz frankoński Fredegar zanotował w swoim dziele, że cesarz Herakliusz (610-641) domagał się od króla Franków Dagoberta (623-639), aby nakazał ochrzcić wszystkich żydów w swoim królestwie, co też Dagobert starał się skrzętnie wypełnićéc

18 Por. Epistolae I 47, PL 77, 510D, nota $e$.

19 Por. Concilium Toletanum IV, can. 56, PL 130, 476B-C: „De Iudaeis autem praecepit sancta synodus nemini deinceps ad credendum vim inferre. Cui enim vult Deus miseretur, et quem vult indurat, non enim tales inviti salvandi sunt, sed volentes, ut integra sit forma iustitiae. Sicut enim homo propria arbitrii voluntate serpenti obediens periit, sic vocante se gratia Dei propriae mentis conversione, homo quisque credendo salvatur. Ergo non vi, sed libera arbitrii voluntate, ut convertantur suadendi sunt non potius impellendi. Qui autem iampridem ad christianitatem coacti sunt sicut factum est temporibus religiosissimi principis Sisebuti, quia iam constat eos sacramentis divinis associatos et baptismi gratiam suscepisse, et chrismate unctos esse, et corporis Domini et sanguinis exstitisse participes, oportet ut fidem etiam quam vi vel necessitate susceperunt, tenere cogantur, ne nomen Domini blasphemetur, et fides quam susceperunt vilis ac contemptibilis habeatur".

${ }^{20}$ Por. Gregorius Turonensis, Historia Francorum VI 17, PL 71, 388, tłum. K. Liman - T. Richter: Historie. Historia Franków, wstęp, opracowanie i komentarz D.A. Sikorski, Kraków 2002, 273: „Król Chilperyk polecił tego roku ochrzcić dużo żydów, z których wielu sam podniósł ze świętego chrztu. Niektórzy wszelako z nich, których ciało jedynie, a nie serce zostało obmyte z grzechów, nie dotrzymali Bogu obietnicy i powrócili do danej niewiary tak, że można było widzieć, iz zachowywali sobotę, jak i święcili niedzielę".

21 Por. Epistolae I 45.

22 Por. Fredegarius, Chronicum I 65, PL 71, 646 C-D „Heraclius [...] ad Dagobertum regem Francorum dirigens, petit ut omnes Iudaeos regni sui ad fidem catholicam baptizandos praeciperet, 
Rozstrzygnięcia św. Grzegorza odwołują się do zasady „konfesyjnej” wolności człowieka, wyłożonej przez św. Augustyna, iż „nikogo wbrew jego woli nie wolno przymuszać do wiary ${ }^{23}$. Napomnieniom papieża do pozyskiwania żydów na drodze łagodnej życzliwości i przekonywania ${ }^{24}$, towarzyszy rodzaj zachęty skierowanej do samych żydów, polegającej na zmniejszeniu nawet o jedną trzecią opłat $\mathrm{z}$ tytułu dzierżawy ${ }^{25}$. Rozwiązanie to dotyczyło Sycylii, gdzie papież posiadał znaczne posiadłości i mógł pozwolić sobie na swobodniejsze decydowanie w sprawach ekonomicznych. Wiadomo zaś, że gest życzliwości zaowocował licznymi nawróceniami wśród żydów ${ }^{26}$. Święty Grzegorz był oczywiście świadom, że przechodzenie na chrześcijaństwo nie zawsze musiało się $\mathrm{w}$ takim przypadku wiązać $\mathrm{z}$ czystą intencją, jednak przeważa według niego i możliwość wewnętrznego zrozumienia i przyjęcia z czasem wiary, jak również dobro dzieci konwertytów, które rodzą się już w wierze ${ }^{27}$.

Postawa łagodności i wychodzenia naprzeciw żydom miała jednak swoje granice, a zrozumienie kończyło się tam, gdzie zaczynała być zagrożona świętość i czystość wiary. Przykład zdecydowanej postawy papieża wiąże się z przypadkiem żyda o imieniu Nazas ${ }^{28}$. Wybudował on w swoich posiadłościach ołtarz poświęcony Eliaszowi i skłaniał wielu chrześcijan do oddawania mu czci (adorare). Byli wśród nich również niewolnicy chrześcijańscy, których Nazas nabył za zgodą pretora Sycylii Justyna. Niewykluczone, iż chodziło w tym przypadku o próbę wymieszania kultu żydowskiego i chrześcijańskiego $^{29}$, czego zakazywało ustawodawstwo Justyniana. Kościół wprawdzie nie zabraniał kultu sprawiedliwych Starego Prawa, o czym świadczy na przykład wybudowanie w Petrium przez cesarza Zenona (474-491) po powrocie z wyprawy perskiej świątyni poświęconej Eliaszowi, jednak do czasów Grzegorza, ani też później na Zachodzie, w przeciwieństwie do Wschodu, nie obchodzono poza jednym wyjątkiem żadnego świątecznego dnia ku czci postaci Starego

quod protinus Dagobertus implevit. Heraclius per omnes provincias imperii talem idemque facere decrevit". Powodem, dla którego Herakliusz domagał się tego, była związana z astrologią zapowiedź, iż zniszczenie cesarstwa przyjdzie ze strony ludów obrzezanych (tamże).

${ }^{23}$ Por. Contra Litteras Petiliani II 83, 184, CSEL 52, 112: „Ad fidem quidem nullus est cogendus invitus".

24 Por. np. Epistolae I 34 i 45; III 26; IV 6.

25 Por. tamże V 7.

26 Por. tamże VIII 23; II 50.

27 Por. tamże V 7, 140, 273: „Nec hoc inutiliter facimus, si pro levandis pensionum oneribus eos ad Christi gratiam perducamus, quia etsi ipsi minus fideliter veniunt, hi tamen qui de eis nati fuerint iam fidelius baptizantur. Aut ipsos ergo, aut eorum filios lucramur. Et ideo non est grave quidquid de pensione pro Christo dimittimus".

${ }^{28}$ Pochodzil on prawdopodobnie ze szlachetnego rodu żyjącego w Palermo, por. Bammel, Gregor der Grosse und die Juden, s. 287, nota 27.

${ }^{29}$ Rozważania na ten temat przedstawia Bammel, Gregor der Grosse und die Juden, s. 286291. 
Testamentu ${ }^{30}$. Ostra reakcja papieża na postępowanie Nazasa może wydawać się zaskakująca, wobec zwykle przyjaznego i pełnego troski o żydów tonu jego listów. Tym razem domaga się on bowiem bezzwłocznego i jak najsurowszego ukarania Nazasa, nie wyłączając kary cielesnej (districtissime ac corporaliter) ${ }^{31}$. Nie dziwi to jednak zważywszy, że jego działania były nie tylko bezprawne, ale godziły w czystość wiary, której strażnikiem czuł się papież przede wszystkim.

Podobnie zdecydowanie zareagował, kiedy dowiedział się, że trzech duchownych z Venafrum sprzedało pewnemu żydowi naczynia z wyposażenia tamtejszego kościoła. Miał on zostać wezwany przed sędziego prowincji i zmuszony do oddania nabytych naczyń. Mimo jednak, iż nabycie to nastąpiło wbrew obowiązującym prawom, jak pisze Grzegorz, to jednak nie wspomina o ukaraniu żyda, podczas gdy mówi o ukaraniu i pokucie dla duchownych, którzy ośmielili się naczynia sprzedać ${ }^{32}$.

2. Wolność wyznania konwertytów. Wyczulenie na możliwość poszerzania katolickiej wiary kierowało w naturalny sposób myśl papieża ku nawracającym się na chrześcijaństwo. Szczególna jego wrażliwość ujawniała się tam, gdzie krzywdy doznawać mogli neofici. Troska o nich przewija się nieustannie w korespondencji św. Grzegorza. Dowodem tego jest pomoc, jakiej udzielił papież małżeństwu Cyriaka i Joanny, którzy z prośbą o opiekę udali się do niego latem 591 r., przybywając z Sycylii do Rzymu. Oboje doznawali przykrości ze strony otoczenia $\mathrm{z}$ powodu tego, iż Joanna przeszła $\mathrm{z}$ religii żydowskiej na chrześcijaństwo. Polecając swemu przedstawicielowi na Sycylii, subdiakonowi Piotrowi, zbadanie i rozwiązanie ich trudności papież odwołuje się do właściwego mu teologicznego sposobu argumentowania swoich postanowień: ,aby za to, że lepszą cząstkę obrała, nie doznawała niepokoju skutkiem sprzeciwu złych ludzi,"33.

Pomoc, jaką starał się okazywać św. Grzegorz nawróconym żydom, przybierała również postać materialną. Papież poleca na przykład Antemiuszowi, zarządcy majątku kościelnego w Kampanii, wypłacanie corocznie nawróconym żydom określonej sumy pieniędzy, aby nie musieli cierpieć głodu ${ }^{34}$.

Świadectwem troski o nawrócenie żydów jest list do obrońcy Fantyna, pełniącego swoją funkcję na Sycylii. Powziąwszy od ksieni klasztoru św. Stefana z rejonu Agrigentum wiadomość o pragnieniu nawrócenia się na chrześcijaństwo wielu spośród tamtejszych żydów poleca papież Fantynowi, bez

30 Wyjątkiem pod tym względem byli Machabeusze, których czczono na Zachodzie w gronie męczenników Kościoła, przynajmniej od początków drugiego tysiąclecia, por. Bernardus Clarvallensis, Epistola 98, PL 182, 230C-234D. Dzień ich wspomnienia przypadał 1 sierpnia.

31 Por. Epistolae III 37, CCL 140, 182-183.

32 Por, tamże I 66.

33 Tamże I 69, CCL 140, 78.

34 Por. tamże IV 31 
względu na jakiekolwiek przeciwne racje, udać się tam w celu umocnienia przy Bożym wsparciu ich zamiaru osobistą zachętą.

List ten ukazuje liturgiczną praktykę stosowaną przez Kościół na Zachodzie w odniesieniu do wyrażających pragnienie przyjęcia sakramentu wiary. Dniem, w którym udzielano chrztu była Wielkanoc. Poza nią, jak informuje o tym Liber diurnus ${ }^{35}$, można było udzielać chrztu tylko w niebezpieczeństwie śmierci. Papież robi w tym przypadku wyjątek polecając Fantynowi, aby jeśli oczekiwanie na chrzest miało się im wydawać zbyt długie i przykre, wyznaczył wraz z miejscowym biskupem jakąś niedzielę lub inną uroczystość, z zachowaniem jednak zasady podjęcia pokuty i czterdziestodniowego postu. Nie tylko więc obawa, by zbytnie oczekiwanie nie ostudziło zapału w dążeniu do przyjęcia chrztu była powodem umożliwienia jego przyspieszenia; skłaniały papieża do takiej decyzji również niosące klęski niespokojne czasy. W przypadku, gdyby żydzi postanowili jednak czekać na Wielkanoc, poleca, aby biskup w okresie katechumenatu odwiedzał ich, troszczył się o nich, i pobudzał ich zapał swoim nauczaniem. Przy tej okazji ujawnia się, jak to zwykle miało miejsce w przypadku Grzegorza, jego troska o ubogich. W poczet swoich rachunków poleca wpisać wydatki na szatę chrzcielną dla tych, których nie byłoby stać na jej zakup.

W nie mniejszym stopniu przedmiotem troski papieża było zapewnienie niewolnikom żydowskim możliwości przejścia na chrześcijaństwo. Jeśli wyrazili taki zamiar, właściciel nie miał prawa sprzedać ich innemu panu, im samym zaś miała być darowana wolność. Właściciele niewolników uważali, iż zasada powyższa obowiązuje ich tylko w odniesieniu do niewolników żydowskich. Tymczasem w liście do Fortunata, biskupa Neapolu ${ }^{36}$, papież precyzuje, że dotyczy ona w równym stopniu niewolników pogańskich. Świadectwo istnienia tego rodzaju interpretacji wskazuje, że wyznający judaizm cieszyli się w tym przypadku większymi prawami niż poganie.

\section{NIEWOLNICY I SŁUŻBA CHRZEŚCIJAŃSKA U ŻYDÓW}

Za czasów św. Grzegorza z niewolnictwem związana była ciągle jeszcze ówczesna ekonomia. Sprzyjały temu głównie prowadzone wojny, przysparzające $\mathrm{z}$ jednej strony niewolniczej taniej siły roboczej, z drugiej zaś brani do niewoli jeńcy stanowili często podstawę zysku, osiąganego dzięki możliwości uzyskania okupu. W obu tych przypadkach mamy poświadczone w listach Grzegorza liczne interwencje, zmierzające do uniemożliwienia, zgodnie z nakazami prawa, służby chrześcijan u żydów, handlu przez nich chrześcijańskimi

${ }^{35}$ Por. Liber diurnus Romanorum Pontificum 6, PL 105, 96.

${ }^{36}$ Por. Epistolae VI 29. 
niewolnikami, bądź też wykorzystywania kontaktów, jakie mieli żydzi poza granicami imperium, dla odzyskiwania (głównie przez wykup) chrześcijan, którzy w czasie wojen popadli w niewolę. Prócz tego, interwencje papieskie dotyczą służby chrześcijan u żydów, zakazanej prawem oraz pomocy tym, którzy jako niewolnicy będąc poganami chcieliby przyjąć chrześcijaństwo. Prześledzimy przykłady tego rodzaju zabiegów św. Grzegorza zwracając uwagę na ówczesną sytuację prawną.

Ustawodawstwo Justyniana zabraniało żydom, poganom i heretykom posiadania niewolników chrześcijańskich. Gdyby zaś miało być inaczej w chwili wprowadzenia ustawy, mieli być oni bezwarunkowo uczynieni wolnymi ${ }^{37}$. Papież wielokrotnie odwołuje się do obowiązującego prawa ${ }^{38}$. Świadczy to, że z problemem tym musiano się stykać dość często. Przykładem może być wspominany list do Libertyna, pretora Sycylii, w sprawie Nazasa. Grzegorz nakazuje w nim wypuścić bez wahania niewolników chrześcijańskich, aby nie doznała skażenia religia chrześcijańska u ludzi poddanych żydom ${ }^{39}$. Jak widać, podkreślanie przez papieża, iż niegodziwością jest, aby chrześcijanie pozostawali na służbie u żydów, wynikało z racji teologicznych ${ }^{40}$.

Podobnego rozwiązania, jak w sprawie Nazasa, tzn. wypuszczenia niewolników, nie można było zastosować, jeśli od dawna byli osadzeni w posiadłościach właściciela dla uprawy roli. W takim przypadku byli bowiem przywiązani do miejsca. Sytuacja taka miała na przykład miejsce w Etrurii, gdzie papież czyni Wenancjusza, biskupa Luny, odpowiedzialnym za to, że dopuścił do tego, iż te ,proste dusze" pozostają w służbie religii żydowskiej, czemu winien zapobiec, nawet nie tyle ze względu na własną gorliwość, co przez wzgląd na

37 Por. Iustiniani Leges selectae. Lex 56, PL 72, 1071D: „Iubemus ut nullus Iudaeus, vel paganus, vel haereticus servos Christianos habeat. Quod si inventi in tali reatu fuerint, sancimus servos omnibus modis liberos esse, secundum anteriorem nostrarum legum tenorem"; zob. też CJ I 9, 4, SCh 497, 424. Jeśli chodzi o posiadanie niewolników przez nie-żydów i nieortodoksyjnych chrześcijan, por. np. Epistolae VIII 21, SCh 140A, 541, gdzie porusza papież również kwestię przejścia właściciela na chrześcijaństwo. Prawo Justyniana wprowadzało ponownie zaostrzenie przepisów w stosunku do ustawy wydanej w 415 r. przez Honoriusza, która zezwalała żydom posiadać niewolników chrześcijańskich pod warunkiem pozwolenia im na zachowanie swojej religii i możliwości jej praktykowania; zob. CTh XVI 9, 3, SCh 497, 422. Prawo Honoriusza było w tym przypadku mniej restrykcyjne niż poprzednie ustawodawstwo Konstantyna. Podtrzymywało wszakże zakaz obrzezywania niewolników, odstępując jednak od bezwzględnego zakazu posiadania niewolników-chrześcijan przez żydów, zob. tamże XVI 9, 2.

${ }^{38}$ Por. np. Epistolae II 45; IV 21.

39 Por. tamże III 37.

40 W tym samym duchu późniejszy IV synod w Toledo postanawiał (Concilium Toletanum IV, can. 65, PL 130, 477-478: „Ex decreto gloriosissimi principis hoc sanctum elegit concilium, ut Iudaeis non liceat Christianos servos, nec Christiana mancipia emere, nec cuiusquam consequi largitatem. Nefas enim est, ut membra Christi serviant Antichristi ministris, quod si deinceps servos Christianos vel ancillas Iudaei habere praesumpserint, sublati ab eorum dominatu libertatem a principe consequantur". 
obowiązujące prawo $^{41}$. W tym przypadku biskup stanął prawdopodobnie przed problemem, którego nie potrafił rozwiązać. Aby to uczynić trzeba było przekształcić sytuację prawną niewolników przez zmianę ich statusu tak, aby pod względem ustawowym byli uważani za kolonów. Ci ostatni zwyczajnie dzielili się na osadników (ascripti) oraz kolonów z nich urodzonych, czyli tzw. originarii. Tych zaś nie można było sprzedawać bez ziemi, którą uprawiali, ponieważ byli do niej przypisani (glebae adcripti). Byli oni związani z ziemią, a nie z panem ziemi. Wskutek wyzwolenia, a zarazem przypisania ich do roli dotychczasowy pan (dominus) niewolników stawał się ich patronem (patronus). Wyzwoleni jako nowi kolonowie mieli odtąd, zgodnie z nakazem papieża, status równy osadnikom i kolonom urodzonym na roli, z obowiązkiem uiszczania patronowi opłaty $z$ tytułu uprawy należącej do niego ziemi ${ }^{42}$. Poza zobowiązaniem do uwalniania niewolników papież zabraniał żydom również przenosić ich na inne miejsce, wykorzystywać do osobistej posługi oraz nakładania na nich jakichkolwiek innych ciężarów ${ }^{43}$.

Niewolnicy żydów, okazujący zamiar przejścia na chrześcijaństwo, nie mogli być sprzedawani przez swoich właścicieli. Ci musieli zapewnić im natomiast wypuszczenie na wolnośćc ${ }^{44}$. Tę samą zasadę każe papież stosować wobec pragnących przyjąć chrzest niewolników należących do pogan. Zakazuje równocześnie żydom, którzy trudnili się handlem niewolnikami, podobnie jak stałym właścicielom, sprzedawania objawiających intencję przyjęcia chrześcijaństwa. Jeśli już zakupieni poza granicami cesarstwa ${ }^{45}$, w ciągu trzymiesięcznego okresu oczekiwania na sprzedanie ich nowemu właścicielowi, objawili taką wolę, wówczas nie wolno ich było sprzedać, a handlarz miał uzyskać z tego tytułu rekompensatę pieniężną od kupca chrześcijańskiego ${ }^{46}$. Kupowani dla zysku, jeśli zostali sprzedani nowemu właścicielowi, mieli możność w ciągu trzech miesięcy od przeprowadzenia transakcji uciec do kościoła i tam objawić intencję przejścia na chrześcijaństwo. Jeśli w ciągu trzech miesięcy handlarz nie znalazł nabywcy, a niewolnik objawił zamiar zostania chrześcijaninem, wówczas nie wolno go było już nikomu sprzedać

41 Por. Epistolae IV 21.

${ }^{42}$ Grzegorz idzie tu za ustawodawstwem cesarskim - CJ XI 48, 6. 11-12. 23. Sytuację prawną osadników omawiają dokładniej F.M. De Robertis (Lavoro e lavoratori nel mondo romano, Bari 1965, co do poruszanego przypadku zob. s. 365nn), oraz V. Recchia (Gregorio Magno e la società agricola, Roma 1978, 67-70).

43 Por. Epistolae IV 21.

${ }^{44}$ Por. tamże VI 29. Zarówno ci, którzy już dawniej byli chrześcijanami, jak i mający przyjąć chrzest, winni mieć zapewnioną wolność, jeśli uciekają do kościoła. Papież zabrania w takim przypadku stosowania praktyki oddawania ich na powrót na służbę do niechrześcijan, jak również zmuszania ich do opłacania się, aby nie zostali im oddani (zob. tamże IV 9).

45 Niewolników kupowano głównie w Galii, por. tamże VI 10; IX 105.

${ }^{46}$ List wydaje się sugerować, że chrześcijański nabywca dla dobra wiary musiał w tym przypadku ponosić ofiarę. 
ani kupić, lecz właściciel na jego korzyść, miał mu darować wolność w ten sposób, iż nie przeznaczał go więcej na sprzedaż, lecz mógł zachować na służbę u siebie ${ }^{47}$.

Wspomniano wyżej, że Grzegorzowi w regulowaniu stosunków posiadania niewolników przyświecała racja teologiczna. Opierając się na niej, papież zabiegał o poszerzenie zasięgu obowiązującego w tym względzie prawa poza granice cesarstwa. W liście do Brunhildy, królowej Franków, odwołuje się do jej chrześcijańskiej postawy. Kto ją ma, nie może jednocześnie oddawać cześć Chrystusowi jako głowie i ,pozwalać, aby członki Jego deptane były przez wrogów". Apeluje zatem, by królowa dokonała zmiany obowiązującego w jej królestwie prawa na korzyść chrześcijańskich niewolników ${ }^{48}$.

W cesarstwie tymczasem prawo dawało niewolnikom możliwość ucieczki od niewiernego pana do kościoła z powodu wiary (fidei causa), a tym samym uzyskanie wolności ${ }^{49}$. Wynikało to już z prawodawstwa Konstantyna, który zabronił żydom posiadania niewolników chrześcijańskich ${ }^{50}$. Kodeksy Teodozjusza i Justyniana podtrzymywały ten zakaz, jak i zakaz obrzezywania niewolników pogańskich ${ }^{51}$. W razie przekroczenia go niewolnik, którego właścicielem był żyd, automatycznie otrzymywał wolność $c^{52}$.

Zdarzały się jednak praktyki oddawania niewolników niewiernym panom lub zmuszania ich do płacenia swego rodzaju okupu, aby nie zostali z powrotem wydani. Zakazując tego rodzaju praktyk, papież przypomina biskupowi Januariuszowi z Caralis, o obowiązku objęcia opieką każdego, kto chroni się w świętym miejscu z powodów związanych z wiarą, bez względu na to, czy od dawna był chrześcijaninem, czy dopiero co przyjął chrzest ${ }^{53}$.

Ujmowanie się za niewolnikami mogło okazać się sprawą nader delikatną. Kiedy urzędnicy państwowi nakazywali kupcom żydowskim nabywanie niewolników w Galii, stawiali ich w trudnej sytuacji. Zdarzało się bowiem, iż byli wśród nich chrześcijanie. Papież, aby nie narażać w takim przypadku na straty handlarzy, wprowadził zasadę, iż zakupieni niewolnicy mieli być przekazywani nakazującym ich kupno sędziom, lub też sprzedani w ciągu czterdziestu dni chrześcijańskim panom. Była to górna granica czasu, przez jaki mogli być oni

47 Por. tamże VI 29.

${ }^{48}$ Por. tamże IX 214, CCL 140A, 775.

49 Por. tamże IV 9; VI 29.

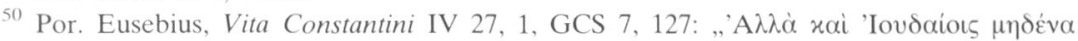

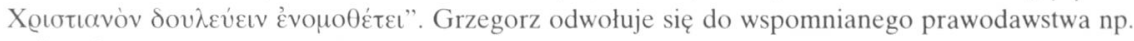
w listach, zob. Epistolae IV 21; VIII 21; IX 214.

51 Por. CTh XVI 9,2; CJ I 10: „Ne Christianum mancipium haereticus vel paganus vel Iudaeus habeat vel possideat vel circumcidat", zob. Epistolae VIII 21

52 Gwarantował to dekret Konstantyna z 336 roku, por. Constantinus, Decreta et constitutiones (Ne christianum manicipium Iudaeus habeat), PL 8, 385D-386A. Właściciel zaś nie otrzymywał za tak wyzwolonego niewolnika żadnej rekompensaty, zob. Epistolae VI 30.

53 Por. Epistolae IV 9. 
w rękach kupców. Rozwiązanie powyższe zapobiegało przebywaniu na służbie u żydów niewolników chrześcijańskich ${ }^{54}$.

Obraz stosunków pomiędzy żydami i chrześcijanami, jaki ukazują nam listy papieża Grzegorza Wielkiego, kształtują trzy główne składowe: jedną z nich stanowi obowiązujące wówczas ustawodawstwo, drugą - napięcia wynikające z odmienności kultury oraz interesów obu społeczności, trzecią - liczne interwencje papieża dotyczące żydów oraz ich relacji z chrześcijanami, mające na celu takie ich kształtowanie, jakie winno wynikać z prawa Ewangelii oraz teologicznego patrzenia na świat. Zasada rozwiązywania trudności w duchu ewangelicznym sprawiała, że podejmowane rozstrzygnięcia miały na celu działanie na rzecz człowieka. Papież nie podzielał krótkowzrocznego działania niektórych biskupów, zmierzających do rozszerzania chrześcijaństwa chćby pod przymusem, mając świadomość, że to, co trwałe i dobre, może rodzić się jedynie z ducha wolności. Stąd łatwo zrozumieć, że w wypełnianiu prawa dotyczącego żydów papież pozwalał sobie czasem na jego obchodzenie tam, gdzie wydawało mu się ono zbyt surowe, niż można to pogodzić z Ewangelią i teologią.

Listy pozwalają nam wniknąć w ducha podejmowanych przez św. Grzegorza decyzji, ale też odsłaniają dziedziny życia społeczności żydowskiej na styku ze światem chrześcijańskim zwłaszcza tam, gdzie dochodziło do sytuacji konfliktowych. Decyzje, jakie musiał podejmować papież w związku z zaistniałymi problemami, dotyczą najczęściej zachowania wolności wyznania religii Mojżeszowej, respektu dla świętości religii chrześcijan, godności niewolników i dobra służby chrześcijańskiej u żydów. Poprzez decyzje te widzimy go jako człowieka zatroskanego nie tylko o dobro chrześcijan, ale również stającego w obronie żydów i pogan, ludzi wolnych i niewolników, duchownych i świeckich. Taka postawa sprawiła, że św. Grzegorz nadał swemu urzędowi wymiar uniwersalny, przekraczający ramy wyznaczone przez świecko pojęte interesy społeczności chrześcijańskiej. Dbając o dobro ludzi, nie należących do wspólnoty wiernych, ukazywał, że jest to postawa wyznaczona duchem Ewangelii. Przyczynił się tym samym do silniejszego postrzegania w przyszłości papiestwa jako urzędu o wymiarze uniwersalnym.

${ }^{54}$ Por. tamże IX 105. 


\section{GREGOIRE LE GRAND ET LES PROBLÈMES LIES AUX RELATIONS ENTRE LES CHRETIENS ET LES JUÏFS D'APRÈS SON REGISTRUM EPISTULARUM}

(Résume)

Tableau des rapports entre les Juïs et les chrétiens que présentent les lettres du pape Grégoire le Grand est formé par trois composantes principales. L'une d'elles constitue la législation alors en vigueur, la suivante évoque les tensions résultant de la différence entre la culture et les intérêts de deux commmunautés, la troisième présente de nombreuses interventions du pape concernant les Juïs et leurs relations avec les chrétiens.

Les Lettres ne nous permettent pas seulement de pénétrer l'esprit des décisions prises par Grégoire le Grand mais elles nous font découvrir les éléments de vie de la commmunauté juïve en contact avec l'univers chrétien, surtout là où apparaient des conflicts.

Les décisions prises par le pape en raison des problèmes existants concernaient avant tout la liberté de pratiquer la religion mosaïque, le respect pour la saintété de la religion chrétienne, la dignité des esclaves et le bien-être des serviteurs chrétiens employés par les Juifs. 